Reka Buana : Jurnal Ilmiah Teknik Sipil dan Teknik Kimia, 4 (1), 2019, page 63-67

Tersedia online di https://jurnal.unitri.ac.id/index.php/rekabuana

ISSN 2503-2682 (Online)

ISSN 2503-3654 (Cetak)

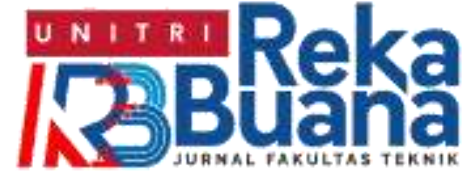

\title{
Kajian Ekstraksi Antosianin dari Buah Murbei dengan Metode Sonikasi dan Microwave
}

\author{
Anitarakhmi Handaratri ${ }^{1}$ dan Yuyun Yuniati ${ }^{2}$ \\ 1) Jurusan Teknik Kimia, Sekolah Tinggi Teknologi Industri Turen, Malang \\ 2) Program Studi Kimia, Fakultas Sains dan Teknologi, Universitas Ma Chung Malang \\ Email : anita.hand@gmail.com
}

\begin{abstract}
ABSTRAK
Pigmen dalam buah murbei (Morus alba L.) yaitu antosianin memiliki potensi fungsional dan komersial di bidang pangan dan obat-obatan. Beberapa peneliti telah mengembangkan metode untuk mendapatkan yield ekstraksi yang tinggi dalam waktu yang singkat. Yield yang tinggi dengan metode Ultrasonic Assisted Extraction menggunakan gelombang ultrasonik yang mempengaruhi dinding sel dan menyebabkan perusakan lapisan tipis dan membantu dalam melepaskan senyawa fenolik yang terperangkap di dalam dinding sel. Metode Microwave Assisted Extraction menggunakan energi dari radiasi microwave untuk memanaskan pelarut dengan cepat dan efisien. Kajian ini menyimpulkan dan memberikan gambaran keunggulan kedua metode tersebut dibandingkan dengan metode konvensional.
\end{abstract}

Kata Kunci : antosianin; ekstraksi; murbei; microwave; ultrasonik

ABSTRACT

The pigment in mulbery (Morus alba L.), anthocyanin, is a kind of natural pigment for food processing and has functional potential and commercial values. Some investigators have developed a method to obtain high extraction yields in a short time. High yields with Ultrasonic Assisted Extraction method using ultrasonic waves that affect the cell wall and causes the destruction of a thin layer and helps in releasing phenolic compounds that trapped in the cell wall. Microwave Assisted Extraction method uses the energy of microwave radiation to heat the solvent quickly and efficiently. This study concludes and gives an overview advantages of both methods were compared with conventional methods.

\section{Keywords: anthocyanin; extraction; mulberry; microwave; ultrasonic}

\section{PENDAHULUAN}

Buah murbei kaya akan pigmen antosianin dan dapat menjadi sumber potensial pewarna makanan alami dan antioksidan yang tinggi. Bentuknya yang kecil, jumlah sedikit, dan masa hidup yang pendek menyebabkan buah ini kurang mendapat perhatian [1].

Ekstraksi pigmen antosianin secara tradisional menggunakan pelarut organik dan dalam kondisi asam [2]. Penggunaan pelarut organik memiliki kelemahan diantaranya mahal dan beracun, sehingga memerlukan penanganan khusus dalam pemurnian antosianin dan pengolahan limbahnya.

Beberapa penelitian melaporkan dalam ekstraksi bahan alam, penggunaan pelarut organik dapat diminimalkan dengan meningkatkan perbandingan jumlah air dan didukung oleh proses yang tepat [3],[4],[5]. Air bersifat sangat ramah lingkungan, 
jumlahnya berlimpah, tidak beracun, dan menjadi media reaksi untuk berbagai aplikasi. Penggunaan air sebagai pelarut ekstraksi dapat menjadi penyelesaian masalah dan bersifat natural untuk mengisolasi antosianin dari buahnya secara efisien bila ekstraksi ditingkatkan [4].

Fokus penelitian di bidang ekstraksi saat ini adalah melakukan optimasi proses thermal dan non thermal yang melibatkan proses bertekanan tinggi dan ultrasonik. Industri makanan akan selalu memilih konsep dan teknologi baru sehingga diperoleh keuntungan berupa pengurangan penggunaan pelarut organik dan konsumsi waktu yang singkat. Pemilihan sistem dan teknologi melalui pertimbangan validasi, verifikasi, akurasi dan efektivitas biaya serta kontrol proses.

Antosianin merupakan pigmen kompleks sehingga memerlukan kondisi tertentu dalam penanganan ekstraksinya. Patras et al. (2010)[6], menyatakan besar dan lamanya pemanasan memiliki pengaruh yang kuat terhadap stabilitas antosianin. Pengembangan teknologi proses ekstraksi menjadi sangat penting untuk mempercepat proses ekstraksi sehingga diperoleh rendemen lebih banyak dan waktu lebih singkat.

\section{METODE KAJIAN}

Tulisan ini difokuskan membahas (mereview) dan mengkaji proses ekstraksi dengan menerapkan teknologi ultrasonik dan microwave. Kelebihan kedua teknologi ini dibandingkan dengan metode maserasi dan sokhletasi adalah rendemen hasilnya yang lebih tinggi. Melalui tulisan ini akan dibuktikan bagaimana gelombang ultrasonik dan microwave akan membuat proses ektraksi pigmen antosianin berlangsung efektif dan singkat.

\section{HASIL DAN PEMBAHASAN}

Ekstraksi fase padat, countercurrent chromatography, adsorpsi, likuid bertekanan atau ekstraksi fluida, dan microwave-assisted extraction termasuk aman bagi lingkungan dengan penggunaan pelarut yang minimum dan mengurangi waktu proses [7]. Jenis kombinasi pelarut yang aman untuk mengektraksi pigmen antosianin adalah air dan asam [8]. Air memiliki sifat konstanta dieletrik tinggi sangat memungkinkan untuk dipakai sebagai pelarut pada ekstraksi dengan metode UAE (Ultrasonic Assisted Extraction) dan MAE (Microvawe Assisted Extraction). Penambahan sedikit asam akan memberikan kestabilan pada pigmen antosianin. Asam yang digunakan dalam ekstraksi antosianin buah murbei pada umumnya adalah asam sitrat.

\section{Ultrasonic Assisted Extraction (UAE)}

Ultrasonik merupakan metode ekstraksi non termal yang dapat meningkatkan laju transfer massa serta memecahkan dinding sel dengan banyaknya microcavity sehingga akan mempersingkat waktu proses dan mengoptimalkan penggunaan pelarut [9]. Peningkatan kecepatan kontak antara ekstrak dan solven menyebabkan peningkatan penetrasi cairan menuju dinding sel dan melepas komponen sel ${ }^{[3]}$. Beberapa kelebihan lain metode UAE adalah dapat mengeluarkan ekstrak dari matriks tanpa merusak merusak struktur ekstrak[10], penggunaan pada temperatur rendah dapat mengurangi kehilangan panas, dan mencegah hilangnya atau menguapnya senyawa yang memiliki titik didih rendah. Sehingga pada saat ini teknik ultrasonik telah 
umum digunakan untuk menyimpan dan mengolah makanan [11].

Winata dan Yunianta mengaplikasikan metode ultrasonik tipe bath untuk mengekstraksi pigmen antosianin pada buah murbei sebagai alternatif pewarna alami. Ekstraksi antosianin dari buah murbei ini menggunakan bantuan alat ultrasonic dengn tipe bath. Variabel yang digunakan adalah lamanya waktu sonikasi dan rasio bahan terhadap pelarut. Hasilnya menunjukkan kedua variable berpengaruh terhadap kadar antosianin, aktivitas antioksidan, $\mathrm{pH}$, rendemen, tingkat kecerahan, tingkat kemerahan dan kekuningan. Pada penelitian tersebut proses ekstraksi dengan ultrasonic bath menghasilkan nilai yang jauh lebih baik pada semua parameter yang diuji. Waktu ekstraksi yang lebih singkat dibandingkan dengan metode perendaman/ maserasi.

Kinetika reaksi untuk ekstraksi antioksidan dengan metode UAE mengikuti reaksi orde dua [13]. Menurut Nguyen et al. (2014)[14] persamaan kinetikanya adalah sebagai berikut :

$$
\begin{aligned}
\frac{d C_{t}}{d t} & =k\left(C_{e}-C_{t}\right)^{2} \\
C_{t} & =\frac{C_{e}^{2} k t}{1+C_{e} k t} \\
\frac{t}{C_{t}} & =\frac{1}{k C_{e}^{2}}+\frac{t}{C_{e}} \\
h & =k C_{e}^{2}
\end{aligned}
$$

Dimana $\mathrm{k}$ adalah konstanta laju reaksi orde dua (L/g.min), $C_{e}$ adalah kapasitas ekstraksi (konsentrasi kesetimbangan antioksidan dalam ekstrak) (g/L), dan $\mathrm{C}_{\mathrm{t}}$ adalah konsentrasi antioksidan dalam ekstrak pada waktu ekstraksi tertentu (g/L). Persamaan (2) merupakan hasil integrasi persamaan umum orde dua dengan kondisi batas $\mathrm{t}=0$ sampai $\mathrm{t}$ dan $\mathrm{C}_{\mathrm{t}}=0$ sampai $\mathrm{C}_{\mathrm{t}}$ yang dapat menjadi persamaan linier (3). Laju ekstraksi mula - mula, h (g/L.min), adalah $\mathrm{C}_{\mathrm{t}} / \mathrm{t}$ ketika $\mathrm{t}$ mendekati 0 , dan dapat dijabarkan seperti persamaan (4).

\section{Microwave Assisted Extraction (MAE)}

Metode MAE digunakan untuk memilih senyawa tertentu yang ditargetkan dari bahan mentah. MAE menggunakan energi dari radiasi microwave untuk memanaskan pelarut dengan cepat dan efisien. Teknologi ekstraksi ini menggunakan aplikasi termal berdasarkan efisiensi produksi panas (pemanasan selektif). Aplikasinya meliputi ekstraksi senyawa bernilai tinggi dari sumber alami, nutraseutikal, dan bahan pangan fungsional, serta bahan aktif dari biomassa.

Pada prosesnya terjadi absorbsi gelombang microwave oleh bagian tanaman, menyebabkan pembengkak-an dan ledakan sel melepaskan komponen - komponennya pada fase likuid. Energi kinetik yang dihasilkan selama pemanasan memicu seluruh massa pada fase likuid untuk meningkatkan laju difusi.[15]

Beberapa faktor yang perlu diperhatikan dalam menggunakan MAE antara lain pemilihan jenis pelarut, lama penggunaan microwave, daya microwave, keunikan matriks, pengaruh kontak luas area sampel, dan efek temperatur terhadap senyawa yang diekstrak [16].

Zou et al. (2012)[17] melakukan eksperimen untuk mengekstrak antosianin dari buah murbei (M. atropurpurea Roxb). Kondisi operasi yang optimum dengan metode MAE adalah sebagai berikut: 59.6\% metanol dalam suasana asam, daya $425 \mathrm{~W}$, rasio liquid dengan solid 25 (v/w), dan waktu 
proses 132 detik. Kondisi operasi tersebut menghasilkan 54,72 $\mathrm{mg}$ antosianin dari 1,0 gram bubuk murbei. Hasil kedua metode
UEA dan MEA dapat dilihat pada tabel berikut :

\begin{tabular}{lcc}
\hline \multicolumn{1}{c}{ Parameter } & $\begin{array}{c}\text { Ultrasonik } \\
\text { Perlakuan terbaik pada } 40^{\circ} \mathrm{C}, 30 \\
\text { menit, rasio bahan : pelarut }=1: 7 \\
(\mathrm{~b} / \mathrm{v})[12]\end{array}$ & $\begin{array}{c}\text { Microwave } \\
\text { Perlakuan terbaik pada } 80 \text { detik, } \\
\text { rasio bahan : pelarut = 1:6 (b/v) } \\
{[18]}\end{array}$ \\
\hline Kadar antosianin (ppm) & 3383,48 & 2434,74 \\
Aktivitas antioksidan IC $_{50}$ & 219,02 & 227,80 \\
$(\mathrm{ppm})$ & 3,16 & 3,32 \\
$\mathrm{pH}$ & 43,52 & 32,78 \\
Rendemen (\%) & 17,5 & 18 \\
Tingkat kecerahan & 7 & 8,70 \\
Tingkat kemerahan & 9 & 15,20 \\
Tingkat kekuningan & & \\
\hline
\end{tabular}

Penggunaan metode konvensional seperti maserasi hanya menghasilkan sekitar 50\% dari hasil ektraksi UEA dan MEA.

\section{KESIMPULAN}

Metode UAE dan MAE merupakan alternatif cara untuk mengekstraksi pigmen antosianin dari buah Murbei. Kedua metode tersebut mampu mengurangi konsumsi waktu dan penggunaan pelarut yang besar. Kualitas rendemen dan hasil ekstrak yang tinggi menunjukkan metode UAE dan MAE sangat efektif dan efisien untuk dikembangkan dalam industri bahan alami.

\section{DAFTAR PUSTAKA}

1. Liu X, Xiao G, Chen W, Xu Y, Wu J. Quantification and Purification of Mulberry Anthocyanins with Macroporous Resins. J Biomed Biotechnol. 2004;5:326-31.

2. Arja FS, Darwis D, Santoni A. Isolasi, Indentifikasi Dan Uji
Antioksidan Senyawa Antosianin Dari Buah Sikaduduk (Melastoma malabathricum L.)Serta Aplikasi Sebagai Pewarna Alami. Kim Unand. 2013;2(1).

3. Wang CC, Chou YY, Sheu SR, Jang MJ, Chen TH. Application of ultrasound thermal process on extracting flavor and caffeine of coffee. Therm Sci. 2011;15(SUPPL.):69-74.

4. Jahangiri $Y$, Ghahremani $H$, Toghabeh JA, Hassani S. The effects of operational conditions on the total amount of anthocyanins extracted from Khorasan's native fig fruit "Ficus carica." Ann Biol Res. 2012;3(5):2181-6.

5. Neliyanti, Idiawati N. Ekstraksi Dan Uji Stabilitas Zat Warna Alami dari Buah Lakum (Cayratia trifolia (L.) Domin). JKK. 2014;3(2):30-7.

6. Patras A, Brunton NP, O’Donnell C, Tiwari BK. Effect of thermal processing on anthocyanin 
stability in foods; mechanisms and kinetics of degradation. Trends Food Sci Technol [Internet]. 2010;21(1):3-11. Available from: http://dx.doi.org/10.1016/j.tifs.2009. 07.004

7. Navas MJ, Jiménez-Moreno AM, Bueno JM, Sáez-Plaza P, G.Asuero A. Analysis and Antioxidant Capacity of Anthocyanin Pigments. Part IV: Extraction of Anthocyanins. Crit Rev Anal Chem. 2010;42(4).

8. Hidayat N, Saati EA. Membuat Pewarna Alami. 1st ed. Surabaya: Trubus Agrisarana; 2006.

9. Shirsath SR, Sonawane SH, Gogate PR. Intensification of Extraction of Natural Products Using Ultrasonic Irradiations-A Review of Current Status. Chem Eng Process Process Intensif. 2012;53:10-23.

10. Babaei R, Jabbari A, Yamini Y. Solid - Liquid Extraction of Fatty Acids of Some Variety of Iranian Rice in Closed Vessel in The Absence and Presence of Ultrasonic Waves. Asian J Chem. 2006;18(1):57-64.

11. Dolatowski ZJ, Stadnik J, Stasiak D. Applications of Ultrasound in Food Technology. Acta Sci Pol, Technol Aliment. 2007;6(3):89-99.

\section{Winata EW, Yunianta.}

Ekstraksi Antosianin Buah Murbei (Morus alba L.) Metode Ultrasonik Bath (Kajian Waktu dan Rasio Bahan: Pelarut). J Pangan dan Agroindustri. 2015;3(2):773-83.
13. Pan Z, Qu W, Ma H, Atungulu GG, McHugh TH. Continuous and Pulsed Ultrasound-Assisted Extractions of Antioxidants from Pomegranate Peel. Ultrason Sonochem. 2011;18(5):1249-57.

14. Nguyen TNT, Phan LHN, Le VVM. Enzyme-assisted and ultrasound-assisted extraction of phenolics from mulberry (Morus alba) fruit: Comparison of kinetic parameters and antioxidant level. Int Food Res J. 2014;21(5):1937-40.

15. Alupului A, Calinescu I, Lavric V. Ultrasonic vs. Microwave extraction intensification of active principles from medicinal plants. In: AIDIC Conference Series. 2009. p. 1023-8.

16. Afoakwah a. N, Owusu J, Adomako C, Teye E. Microwave Assisted Extraction (MAE) of Antioxidant Constituents in Plant Materials. Glob J Bio-science Biotechnol. 2012;1(2):132-40.

17. Zou T, Wang D, Guo H, Zhu Y, Luo X, Liu F, et al. Optimization of Microwave-Assisted Extraction of Anthocyanins from Mulberry and Identification of Anthocyanins in Extract Using HPLC-ESI-MS. J Food Sci. 2012;71(1):46-50.

18. N. Azmi and Yunianta, "Ekstraksi Antosianin dari Buah Murbei (Morus alba L.) Metode Microwave Assisted Extraction (Kajian Waktu Ekstraksi dan Rasio Bahan: Pelarut)," J. Pangan dan Agroindustri, vol. 3, no. 3, pp. 835846, 2015. 